\title{
Immunofluorescence microscopy of healthy skin from patients with systemic lupus erythematosus: more than just the lupus band
}

\author{
P J Velthuis, L Kater, I van der Tweel, H Baart de la Faille, W A van Vloten
}

Department of

Dermatology,

University of Utrecht,

Heidelberglaan 100,

3584 CX Utrecht,

The Netherlands

P J Velthuis

H Baart de la Faille

W A van Vloten

Division of

Immunopathology,

Department of

Internal Medicine,

University of Utrecht,

Heidelberglaan 100,

3584 CX Utrecht,

The Netherlands

L Kater

Centre for Biostatistics,

University of Utrecht,

Heidelberglaan 100,

3584 CX Utrecht,

The Netherlands

I van der Tweel

Correspondence to:

Dr P J Velthuis,

PO Box 90 ,

$5660 \mathrm{AB}$ Geldrop,

The Netherlands.

Accepted for publication

25 October 1991

\begin{abstract}
Many papers have been published on the lupus band in systemic lupus erythematosus (SLE), but little information exists on the possible diagnostic value of the lupus band and other microscopic immunofluorescence phenomena found in clinically normal skin of patients with SLE.

In a study of 297 subjects (66 patients with SLE, 81 patients with other forms of LE, and 150 patients with other systemic connective tissue disorders) it was found that: (a) granular deposits of $\operatorname{IgA}, \operatorname{IgG}$, and $\operatorname{IgM}$ in the basal membrane zone and in the deeper blood vessels were more common in patients with SLE than in the other two groups; $(b)$ depending on the clinical differential diagnosis, IgA and IgG deposits at the epidermal basal membrane can be specific for SLE; (c) using logistic regression analysis sets of variables can be selected with a high potential to discriminate between SLE and the other groups; and $(d)$ immunofluorescence variables do not duplicate the information for the diagnosis of SLE given by the American Rheumatism Association (ARA) criteria or other laboratory methods.
\end{abstract}

From these results, it is concluded that immunofluorescence microscopy of clinically normal skin is a valuable diagnostic method which should be reconsidered as a potential criterion for the diagnosis of SLE in the next evaluation of the ARA criteria.

Immunofluorescence microscopy of clinically normal skin is considered to be a useful marker for systemic lupus erythematosus (SLE). Positive results can be found before any other laboratory test in SLE. ' In a 10 year prospective study it was found to detect a subgroup of patients with a worse prognosis. ${ }^{2}$ It has not been included as a criterion for the diagnosis by the American Rheumatism Association (ARA), however. ${ }^{3}$ In a multicentre study the sensitivity and specificity of the skin biopsy test were relatively high (68 and $81 \%$ ), but the method was eliminated from the final data analysis as it was seldom performed. ${ }^{3}$

In $60-70 \%$ of patients with SLE, immunoglobulins and complement components (immunoreactants) are deposited in a band-like manner at the basal membrane zone of clinically healthy skin (the basal membrane phenomenon is referred to as the lupus band). ${ }^{1}$ These deposits (especially of the IgM type) are not specific for SLE as they can also be shown, though less often, in other systemic connective tissue diseases, such as mixed connective tissue disease $(50 \%),{ }^{4}$ rheumatoid arthritis (RA; $\left.66 \%\right),{ }^{5}$ and primary Sjögren's syndrome $(8 \%),{ }^{6}$ and even in healthy control subjects $(13-21 \%){ }^{7-9}$ Smith et al observed increased specificity of immunofluorescence microscopy for SLE with the number of immunoreactants found at the basal membrane zone. ${ }^{10}$ They did not consider the types, though it seems from their data that some (IgA, C3) were likely to be more specific than others $(\operatorname{Ig} M){ }^{10}$

Immunoreactants are often not distributed along the full length of the basal membrane zone, and therefore do not form a continuous lupus band. The implication of this phenomenon for the use of immunofluorescence microscopy as a diagnostic method in SLE has not yet been investigated. In addition, other features of immunofluorescence are also recognised in SLE-that is, epidermal nuclear IgG deposits (the in vivo antinuclear antibody staining phenomenon $)^{11}$ and deposits of immunoreactants in the blood vessel walls. ${ }^{12-15}$

The aim of this study was to investigate which variables or combination of variables in immunofluorescence microscopy of clinically normal skin are most useful in terms of specificity, sensitivity, predictive value, and efficiency for the diagnosis of SLE. We considered not only the presence of the deposits at the basal membrane zone, but also their complexity, their distribution along the basal membrane zone, the complexity and localisation of deposits in vessel walls, and the presence of the in vivo antinuclear antibody phenomenon. Furthermore, we examined whether skin immunofluorescence yields information additional to clinical and serological parameters in SLE, or whether it is merely a redundant method.

\section{Patients and methods}

PATIENTS

This study was of 297 patients who visited the outpatient clinics of the departments of rheumatology, immunopathology, or dermatology of the University Hospital Utrecht in 1987, and in whom, after informed consent, a biopsy sample of clinically healthy skin was taken. This study covered almost the same population as described previously. " The clinical, serological, and immunofluorescence data of all these patients were analysed.

Three groups of patients were formed: group I, 66 patients with SLE; group II, 81 patients with other LE forms; and group III, 150 patients with other systemic connective tissue diseases (table 1). In these groups the mean 
Table 1 Occurrence of immunofluorescence parameters in various connective tissue disorders. Values are percentages per diagnosis

\begin{tabular}{|c|c|c|c|c|c|c|c|c|c|c|}
\hline \multirow[t]{2}{*}{ Diagnoses" } & & \multicolumn{4}{|c|}{ Basal membrane zone } & \multicolumn{4}{|c|}{ Blood vessel walls } & \multirow{2}{*}{$\begin{array}{l}\text { In vivo } \\
\text { antinuclear } \\
\text { antibodies }\end{array}$} \\
\hline & & $I g A$ & $\operatorname{Ig} G$ & $\operatorname{Ig} M$ & C3 & $\operatorname{Ig} A$ & $\operatorname{Ig} G$ & $I g M$ & C3 & \\
\hline Group I: SLE & $(\mathrm{n}=66)$ & 37 & 57 & 67 & 43 & 38 & 38 & 67 & 33 & 24 \\
\hline $\begin{array}{l}\text { Group II: other LE forms } \\
\text { DLE (no other ARA criteria) } \\
\text { DLE+one other ARA criterion } \\
\text { DLE+ two other ARA criteria } \\
\text { Three ARA criteria no skin sign } \\
\text { SCLE } \\
\text { SCLE (four ARA criteria)† }\end{array}$ & $\begin{array}{l}(n=81) \\
(n=20) \\
(n=24) \\
(n=9) \\
(n=7) \\
(n=21) \\
(n=8)\end{array}$ & $\begin{array}{r}5 \\
4 \\
22 \\
29 \\
5 \\
63\end{array}$ & $\begin{array}{l}20 \\
17 \\
22 \\
14 \\
24 \\
75\end{array}$ & $\begin{array}{l}35 \\
37 \\
33 \\
57 \\
33 \\
75\end{array}$ & $\begin{array}{r}5 \\
12 \\
11 \\
0 \\
29 \\
38\end{array}$ & $\begin{array}{r}5 \\
17 \\
11 \\
14 \\
5 \\
50\end{array}$ & $\begin{array}{r}25 \\
17 \\
22 \\
43 \\
5 \\
25\end{array}$ & $\begin{array}{l}20 \\
25 \\
44 \\
57 \\
24 \\
63\end{array}$ & $\begin{array}{r}5 \\
8 \\
44 \\
0 \\
19 \\
25\end{array}$ & $\begin{array}{r}0 \\
4 \\
0 \\
43 \\
24 \\
50\end{array}$ \\
\hline \multicolumn{11}{|c|}{ Group III: other systemic connective tissue disorders $(n=150)$} \\
\hline $\begin{array}{l}\text { Acrosclerosis } \\
\text { Localised } \\
\text { Rheumatoid arthritis } \\
\text { Mixed connective tissue disease }\end{array}$ & $\begin{array}{l}(n=31) \\
(n=14) \\
(n=17) \\
(n=6)\end{array}$ & $\begin{array}{l}3 \\
0 \\
0 \\
0\end{array}$ & $\begin{array}{l}3 \\
0 \\
0 \\
0\end{array}$ & $\begin{array}{r}6 \\
0 \\
59 \\
50\end{array}$ & $\begin{array}{l}0 \\
0 \\
0 \\
0\end{array}$ & $\begin{array}{r}0 \\
0 \\
18 \\
17\end{array}$ & $\begin{array}{r}0 \\
0 \\
18 \\
17\end{array}$ & $\begin{array}{r}0 \\
0 \\
53 \\
50\end{array}$ & $\begin{array}{r}0 \\
0 \\
41 \\
33\end{array}$ & $\begin{array}{r}52 \\
0 \\
0 \\
100\end{array}$ \\
\hline $\begin{array}{l}\text { Wegener's disease and periarteritis } \\
\text { nodosa } \\
\text { DM/PM }\end{array}$ & $\begin{array}{l}(n=9) \\
(n=35)\end{array}$ & 0 & 0 & 11 & 0 & 22 & 11 & 22 & 11 & 0 \\
\hline $\begin{array}{l}\text { Types } 1-4 \\
\text { Type } 5\end{array}$ & $\begin{array}{l}(n=21) \\
(n=14)\end{array}$ & $\begin{array}{r}0 \\
21\end{array}$ & $\begin{array}{r}0 \\
21\end{array}$ & $\begin{array}{l}14 \\
29\end{array}$ & $\begin{array}{r}5 \\
14\end{array}$ & $\begin{array}{r}0 \\
21\end{array}$ & $\begin{array}{r}0 \\
14\end{array}$ & $\begin{array}{r}5 \\
36\end{array}$ & $\begin{array}{r}0 \\
14\end{array}$ & $\begin{array}{l}33 \\
79\end{array}$ \\
\hline $\begin{array}{l}\text { Raynaud's syndrome } \\
\text { Primary } \\
\text { Secondary } \ddagger\end{array}$ & $\begin{array}{l}(n=88) \\
(n=20) \\
(n=68)\end{array}$ & $\begin{array}{l}0 \\
6\end{array}$ & $\begin{array}{l}0 \\
4\end{array}$ & $\begin{array}{l}15 \\
13\end{array}$ & 5 & $\begin{array}{r}10 \\
6\end{array}$ & $\begin{array}{r}10 \\
3\end{array}$ & $\begin{array}{r}10 \\
7\end{array}$ & $\begin{array}{r}10 \\
4\end{array}$ & $\begin{array}{l}10 \\
43\end{array}$ \\
\hline Siögren's syndrome & $(n=27)$ & & & & & & & & & \\
\hline $\begin{array}{l}\text { Primary } \\
\text { Secondary } \ddagger\end{array}$ & $\begin{array}{l}(n=18) \\
(n=9)\end{array}$ & $\begin{array}{r}17 \\
0\end{array}$ & $\begin{array}{r}11 \\
0\end{array}$ & $\begin{array}{l}22 \\
11\end{array}$ & $\begin{array}{r}11 \\
0\end{array}$ & $\begin{array}{r}22 \\
0\end{array}$ & $\begin{array}{l}17 \\
11\end{array}$ & $\begin{array}{l}28 \\
11\end{array}$ & $\begin{array}{l}17 \\
11\end{array}$ & $\begin{array}{l}56 \\
56\end{array}$ \\
\hline
\end{tabular}

${ }^{*}$ Abbreviations: (SLE) systemic lupus erythematosus; (DLE) discoid lupus erythematosus; (SCLE) subacute cutaneous lupus erythematosus; (SCTD) systemic connective tissue disease; (DM/PM) dermato/polymyositis; (MCTD) mixed connective tissue disease. DM/PM types 1-4 not associated with SCTD; type 5 associated with SCTD.

TSLE with skin signs of subacute LE; these patients were also included in the group of patients with SLE.

$\ddagger$ Also included in other diagnostic groups.

(range) ages (in years) were: 38 (17-75), 45 (22-75), and 47 (4-84). The mean (range) periods between the initial symptoms and the time the biopsy sample was taken (in years) were: $12(2-43), 11(1-41)$, and $9(1-62)$.

For the diagnosis of SLE the 1982 ARA criteria were used. ${ }^{3}$ Table 2 gives a comparison between the occurrence of the ARA criteria in this group and in the group in the study of Tan et $a l .^{3}$ The diagnoses of discoid and subacute cutaneous LE were based on clinical, histological and immunofluorescence features of the diseased skin. ${ }^{1617}$ For the diagnoses of RA, dermato/polymyositis, various forms of scleroderma, primary Sjögren's syndrome, mixed connective tissue disease, Wegener's disease, periarteritis nodosa, and primary Raynaud's phenomenon, widely accepted criteria were used. ${ }^{18}$ Sjögren's syndrome and Raynaud's phenomenon were considered secondary when accompanied by a systemic connective tissue disease.

BLOOD SAMPLES

The presence of antinuclear antibodies in serum

Table 2 Occurrence of 1982 ARA criteria ${ }^{3}$ in the group of patients with SLE compared with the 1982 ARA study group. Values given as percentages

\begin{tabular}{lll}
\hline Criteria & $\begin{array}{l}\text { This study } \\
(n=66)\end{array}$ & $\begin{array}{l}1982 \text { ARA } \\
\text { study } \\
(n=177)\end{array}$ \\
\hline Malar rash & 39 & 57 \\
Discoid rash & 40 & 18 \\
Photosensitivity & 31 & 43 \\
Oral ulcerations & 21 & 27 \\
Arthritis & 75 & 86 \\
Serositis & 33 & 56 \\
Renal disease & 46 & 51 \\
Neurological disease & 15 & 20 \\
Haematological disease & 73 & 59 \\
Immunological disease & 81 & 85 \\
Antinuclear antibodies & 91 & 99 \\
\hline
\end{tabular}

samples was tested by an indirect immunofluorescence technique on mouse liver sections. Titres $\geqslant 1 / 100$ were considered positive. Antibodies to extractable nuclear antigens, native ribonucleoprotein, Sm, SSA-Ro, and SSB-La were tested for by counterimmunoelectrophoresis with reference serum samples from CDC (Atlanta, GA, USA). Antibodies to double stranded DNA were tested by indirect immunofluorescence on Crithidia luciliae and the Farr assay. Rheumatoid factors were determined by the latex RF test (RA test; Behring Werke). Circulating immune complexes were determined by the Clq binding assay ${ }^{19}$ and the indirect granulocyte phagocytosis test. ${ }^{20}$ Other blood parameters included haemoglobin, leucocyte, lymphocyte, and thrombocyte counts, haemolytic complement (CH50), complement components $\mathrm{Clq}, \mathrm{C} 4, \mathrm{C} 3$, and the direct Coombs' test.

\section{IMMUNOFLUORESCENCE OF THE SKIN SAMPLES} Punch biopsy samples ( $3 \mathrm{~mm}$ ) were taken from clinically normal skin of the extensor surface of the forearm. The biopsy samples were snap frozen in liquid nitrogen and stored at $-70^{\circ} \mathrm{C}$ for a maximum of one week before processing. Frozen tissue samples were cut at $4 \mu \mathrm{m}$ and sections were air dried and then washed in phosphate buffered saline (PBS; pH 7.2) for 30 minutes. Sections were tested for the presence of the immunoreactants IgA, IgG, IgM, and C3 using commercially available FITC conjugates (Dakopatts, Copenhagen, Denmark) by incubation in a humid chamber at room temperature for 30 minutes. The sections were then washed again in PBS for 30 minutes and mounted under glass coverslips with a solution of $10 \%$ glycerol in PBS. The specificity of all the serum samples containing antibodies was confirmed by crossed immunoelectrophoresis 
and double immunodiffusion. In double immunodiffusion, no reaction with purified $x$ and $\lambda$ chains was observed. Monospecificity for the various heavy chains of primary serum samples containing antibodies was also tested with an enzyme linked immunosorbent assay (ELISA) with human $\operatorname{IgA}, \operatorname{IgG}$, and $\operatorname{IgM}$ as antigens, and on monoclonal plasma cells in bone marrow biopsy specimens obtained from selected patients with myeloma. Optimal working dilutions were established by chessboard titrations on frozen skin sections with a known specific immunofluorescence pattern and were found to be 1/30 in PBS for all conjugates used. All slides were assessed with a Zeiss microscope equipped for dark field fluorescence.

Deposits were either granular or homogeneous; linear deposits were not found. Their distribution along the basal membrane zone was classified into three categories: focal (1-25\% of the basal membrane zone length), discontinuous $(26-75 \%)$, or continuous $(>75 \%)$. Scanty deposits (distribution $<1 \%$ ) were disregarded. Blood vessel wall deposits were considered positive if one or more vessels showed granular staining in the pars papillaris (superficial vessels), the pars reticularis (deeper vessels), or in these two locations. The in vivo antinuclear antibody staining phenomenon was considered positive when epidermal cell nuclei showed deposits of IgG. When found, IgA and IgM staining was always concomitant with IgG staining and was therefore not considered separately.

\section{STATISTICAL ANALYSIS}

All statistical analyses were performed with SPSS-X or SPSS-PC+ $(2 \cdot 0)$ using a CYBER 180/855 computer (Academisch Computer Centrum Utrecht) or an Olivetti personal computer, except for the logistic regression analysis which was performed with BMDP using the CYBER 180/855. The following nine immunofluorescence variables were considered: in vivo antinuclear antibody staining in the epidermis, IgA, IgG, IgM, C3 at the basal membrane zone, and IgA, IgG, IgM, and C3 in the vessel walls. In addition to the presence or absence of these immunofluorescence variables, other aspects were distinguished-that is, at the basal membrane zone, distribution of the deposits (focal, discontinuous, or continuous); and in the vessel walls, the localisation of the affected vessels (superficial, deep, or superficial and deep).

The relationship between the separate immunofluorescence variables (or combinations of immunofluorescence variables) and the probability of SLE was examined using logistic regression analysis. From the results of this analysis, the probability of SLE can be predicted for each selected (combination of) immunofluorescence variable(s). This predicted proportion is the number of patients with SLE with the selected immunofluorescence variable(s) divided by the number of all patients studied with the selected immunofluorescence variable(s).

The statistical parameters tested were:

\begin{tabular}{|c|c|}
\hline \multirow{2}{*}{ sensitivity } & $\begin{array}{l}\text { patients with SLE with this } \\
\text { immunofluorescence variable }\end{array}$ \\
\hline & all patients with SLE \\
\hline \multirow{4}{*}{ predictive values SLE } & $\begin{array}{l}\text { non-SLE patients without this } \\
\text { immunofluorescence variable }\end{array}$ \\
\hline & all non-SLE patients \\
\hline & $\begin{array}{l}\text { patients with SLE with this } \\
\text { immunofluorescence variable }\end{array}$ \\
\hline & $\begin{array}{l}\text { all patients with this } \\
\text { immunofluorescence variable }\end{array}$ \\
\hline \multirow{2}{*}{$\begin{array}{l}\text { predictive value } \\
\text { other diagnoses }\end{array}$} & $\begin{array}{l}\text { non-SLE patients without this } \\
\text { immunofluorescence variable }\end{array}$ \\
\hline & $\begin{array}{l}\text { all patients without this } \\
\text { immunofluorescence variable }\end{array}$ \\
\hline \multirow{2}{*}{ efficiency } & $\begin{array}{l}\text { patients with SLE with this variable } \\
+ \text { non-SLE patients without } \\
\text { this variable }\end{array}$ \\
\hline & all patients tested \\
\hline
\end{tabular}

*Or combination of immunofluorescence variables.

\section{Results}

Table 1 gives the frequency of all immunofluorescence variables in the various disorders. All variables, except in vivo antinuclear antibodies, were found to be significantly more common in group I subjects than in groups II and III (Fisher's exact test: $p<0.025)$. Deposits of $\operatorname{IgA}(p<0.025), \operatorname{IgG}(p=0.04)$, and $\operatorname{Ig} M$ $(p=0.09)$ at the basal membrane zone and IgA in the blood vessel walls $(\mathrm{p}<0.025)$ were significantly more common in those patients with subacute cutaneous lupus erythematosus with four or more ARA criteria than those without (Fisher's exact test).

Table 3 gives the occurrence of the various distributions along the basal membrane zone. Continuous deposits of $\operatorname{IgA}, \operatorname{IgG}$, and IgM were significantly more common in group I subjects than in groups II and III ( $\chi^{2}$ test; $\left.p<0.05\right)$.

Table 4 gives the occurrence of the different

Table 3 Distribution of immunofluorescence deposits at the basal membrane zone. Values are percentage of patients positive

\begin{tabular}{|c|c|c|c|c|c|c|c|c|c|c|c|c|c|c|c|c|}
\hline \multirow[t]{2}{*}{ Group } & \multicolumn{3}{|c|}{$I g A t$} & \multirow[t]{2}{*}{ Tott } & \multicolumn{3}{|c|}{$I g G t$} & \multirow[t]{2}{*}{ Tott } & \multicolumn{3}{|c|}{ IgMt } & \multirow[t]{2}{*}{ Totf } & \multicolumn{3}{|l|}{ C3t } & \multirow[t]{2}{*}{ Totf } \\
\hline & Foc & Dis & Con & & $F o c$ & Dis & Con & & $F o c$ & Dis & Con & & Foc & Dis & Con & \\
\hline $\begin{array}{l}\text { I (SLE) } \\
\text { II (LE) } \\
\text { III (SCTD) }\end{array}$ & $\begin{array}{l}6 \\
6 \\
1\end{array}$ & $\begin{array}{r}11 \\
2 \\
3\end{array}$ & $\begin{array}{r}20 \\
1 \\
1\end{array}$ & $\begin{array}{r}37 \\
9 \\
5\end{array}$ & $\begin{array}{r}14 \\
8 \\
1\end{array}$ & $\begin{array}{l}5 \\
6 \\
0\end{array}$ & $\begin{array}{r}38 \\
6 \\
3\end{array}$ & $\begin{array}{r}57 \\
20 \\
4\end{array}$ & $\begin{array}{r}14 \\
11 \\
8\end{array}$ & $\begin{array}{r}11 \\
14 \\
7\end{array}$ & $\begin{array}{r}42 \\
12 \\
5\end{array}$ & $\begin{array}{l}67 \\
37 \\
20\end{array}$ & $\begin{array}{r}23 \\
10 \\
3\end{array}$ & $\begin{array}{l}8 \\
2 \\
0\end{array}$ & $\begin{array}{r}12 \\
1 \\
1\end{array}$ & $\begin{array}{r}43 \\
13 \\
4\end{array}$ \\
\hline
\end{tabular}

(SLE) systemic lupus erythematosus (66 patients): (LE) other forms of lupus erythematosus (81): and (SCTD) other systemic connective tissue disorder (150). tDistribution of the deposits: (Foc) focal: (Dis) discontinuous: and (Con) continuous. (Tot) total prevalence. 
localisations of immunofluorescence deposits in blood vessel walls. If present, deposits of IgA, IgG, and IgM were always found in the superficial vessel walls. In a number of subjects they were also present in the walls of deeper vessels. This combination was significantly more common in group I subjects than in groups II and III $\left(\chi^{2}\right.$ test; $\left.\mathrm{p}<0 \cdot 05\right)$.

Tables 5 and 6 give the results of the statistical parameters for different combinations of immunofluorescence parameters. Considering all immunofluorescence variables in logistic regression analysis for the purpose of discriminating between groups I and II, the best variables selected were $(a)$ the presence of IgM deposits (simultaneously in superficial and deeper vessels) and $(b)$ the presence of continuous IgG deposits at the basal membrane zone (table 5). To discriminate between groups I and III, the following four appeared to be superior: (a) the presence of IgM deposits in vessels (irrespective of location); $(b)$ the presence of continuous IgM deposits at the basal membrane zone; (c) the presence of $\mathrm{C} 3$ deposits at the basal membrane zone (irrespective of distribution); and $(d)$ the absence of in vivo antinuclear antibody staining. As there are 16 different possible combinations of these variables, the statistical parameters are given as an example (table 6) only for the combinations in which the predicted proportion of patients SLE was higher than $16 \%$ (this is the predicted proportion when these four immunofluorescence variables were all negative).

Using the $\chi^{2}$ test to find the ARA criteria significantly associated with immunofluorescence variables, seven pairs were found $\left(\chi^{2}\right.$ test, $\mathrm{p}<0.05$; table 7 ). McNemar's test was used to investigate which side of the association was the most sensitive for the diagnosis of SLE (table 7). From all blood parameters, only high titre serum antinuclear antibodies $(\mathrm{p}<0.05)$ and antibodies to double stranded DNA $(0.05<$ $\mathrm{p}<0 \cdot 10)$ were associated with an immunofluorescence variable-that is, IgG at the basal membrane zone $\left(\chi^{2}\right.$ test $)$.

Table 7 Significant associations of immunofluorescence parameters and ARA criteria and comparison of their relative value for the diagnosis of systemic lupus erythematosus. $B M Z=$ basal membrane zone

IgA $(\mathrm{BMZ})=\operatorname{IgG}(\mathrm{BMZ})=\mathrm{C} 3($ vessels $)=$ malar rash Absence of in vivo antinuclear antibodies $>$ renal disease IgG $(B M Z)>$ light sensitivity

C3 $(B M Z)>$ neurological disorders

IgG (BMZ) <antinuclear antibodies

$(>)$ parameter on the left side was found significantly more often. $(<)$ parameter on the right side was found significantly more

$(=)$ no significant difference $(M c N e m a r ' s$ test; $\mathrm{p}<0.05$ )

Table 4 Localisation of immunofluorescence deposits in blood vessel walls. Values are percentage of patients positive

\begin{tabular}{|c|c|c|c|c|c|c|c|c|c|c|c|c|}
\hline \multirow[t]{2}{*}{ Group: } & \multicolumn{2}{|c|}{$\operatorname{Ig} A t$} & \multirow[t]{2}{*}{ Tott } & \multicolumn{2}{|c|}{ IgGt } & \multirow[t]{2}{*}{ Tott } & \multicolumn{2}{|c|}{$I g M t$} & \multirow[t]{2}{*}{ Tott } & \multicolumn{2}{|l|}{$C: 3 t$} & \multirow[t]{2}{*}{ Tott } \\
\hline & Sup & $S+d$ & & Sup & $S+d$ & & Sup & $S+d$ & & Sup & $S+d$ & \\
\hline $\begin{array}{l}\text { I (SLE) } \\
\text { II (LE) } \\
\text { III (SCTD) }\end{array}$ & $\begin{array}{l}8 \\
8 \\
5\end{array}$ & $\begin{array}{r}30 \\
2 \\
5\end{array}$ & $\begin{array}{l}38 \\
10 \\
10\end{array}$ & $\begin{array}{r}9 \\
12 \\
4\end{array}$ & $\begin{array}{r}29 \\
7 \\
4\end{array}$ & $\begin{array}{r}38 \\
19 \\
8\end{array}$ & $\begin{array}{l}26 \\
21 \\
11\end{array}$ & $\begin{array}{r}41 \\
8 \\
7\end{array}$ & $\begin{array}{l}67 \\
29 \\
18\end{array}$ & $\begin{array}{r}18 \\
14 \\
7\end{array}$ & $\begin{array}{r}15 \\
0 \\
4\end{array}$ & $\begin{array}{l}43 \\
14 \\
11\end{array}$ \\
\hline
\end{tabular}

*(SLE) systemic lupus erythematosus (66 patients): (LE) other forms of lupus erythemattosus (SI): and (SC "TD)) other systemic connective tissue disorder (150).

tImmunofluorescence deposits in: (Sup) superficial vessels: $(S+d)$ superficial+decper vessels: and (Tot) total previalence.

Table 5 Statistical parameters of different combinations of immunofluorescence parameters; systemic lupus erythematosus (SLE) (66 patients) versus other LE forms ( 81 patients)

\begin{tabular}{llllll}
\hline Immunofluorescence parameters & Sensitivity & Specificity & PV (SLE) & PV (LE) & Efficiency \\
\hline $\begin{array}{l}\text { One or more immunoreactants at the basal } \\
\text { membrane zone }\end{array}$ & 0.73 & 0.52 & 0.56 & 0.70 & 0.62 \\
$\begin{array}{l}\text { Two or more immunoreactants at the basal } \\
\text { membrane zone or in vessels, or both }\end{array}$ & 0.74 & 0.63 & 0.62 & 0.76 & 0.68 \\
$\begin{array}{l}\text { Two or more immunoreactants at the basal } \\
\text { membrane zone }\end{array}$ & 0.60 & 0.80 & 0.70 & 0.71 & 0.71 \\
$\begin{array}{l}\text { IgM in vessels or continuous IgG at the basal } \\
\text { membrane zonet }\end{array}$ & 0.24 & 0.99 & 0.94 & 0.62 & 0.80 \\
\hline
\end{tabular}

*PV (SLE) predictive value systemic lupus erythematosus; PV (LE) predictive value other forms of lupus erythematosus. †Best possible combination (computed by logistic regression analysis; see text).

Table 6 Statistical parameters of different combinations of immunofluorescence parameters; systemic lupus erythematosus $(S L E)$ (66 patients) versus other systemic connective tissue disease forms (SCTD) (150 patients)

\begin{tabular}{llllll}
\hline Immunofluorescence parameters & Sensitivity & Specificity & PV $(S L E)^{*}$ & PV $(S C T D)^{*}$ & Efficiency \\
\hline $\begin{array}{l}\text { One or more immunoreactants at the basal } \\
\text { membrane zone }\end{array}$ & 0.70 & 0.82 & 0.59 & 0.88 & 0.79 \\
$\begin{array}{l}\text { Two or more immunoreactants at the basal } \\
\text { membrane zone or in vessels, or both }\end{array}$ & 0.75 & 0.84 & 0.90 & 0.71 & 0.86 \\
$\begin{array}{l}\text { Two or more immunoreactants at the basal } \\
\text { membrane zone }\end{array}$ & 0.60 & 0.96 & 0.83 & 0.87 & 0.81 \\
$\begin{array}{l}\text { IgM in vessels or C3 at the basal membrane zone } \\
\text { or IgM continuous at the basal membrane }\end{array}$ & zone or absence of in vivo antinuclear \\
antibody stainingt
\end{tabular}

*PV (SLE) predictive value systemic lupus erythematosus; PV (SCTD) predictive value other systemic connective tissue disorders. †Best possible combination (computed by logistic regression analysis; see text). 


\section{Discussion}

This study indicates that immunofluorescence microscopy of clinically healthy skin can be a helpful diagnostic test for SLE. Its diagnostic potential can only be fully appreciated, however, when immunofluorescence is regarded as a histopathological method. This means that in the process of making a diagnostic decision the immunopathologist has to take into account more than just the presence or absence of the 'lupus band': the type of immunoreactant found and the exact localisation of the deposits have to be considered. Furthermore, the clinical differential diagnosis should be considered.

Referring to deposits of IgA or IgG, or both, at the basal membrane zone, a good differentation can be made between SLE, in which these immunoglobulins can often be found, and scleroderma, RA, mixed connective tissue disease, Wegener's disease, periarteritis nodosa, and dermato/polymyositis (types 1-4) (table 1). Patients with SLE with systemic cutaneous lupus erythematosus type skin disease can be distinguished from those with systemic cutaneous lupus erythematosus not meeting four or more ARA criteria by deposits of IgA at the basal membrane zone or in the blood vessel walls, and to a lesser extent by deposits of IgG and $\operatorname{IgM}$ at the basal membrane zone (table 1 ). In contrast to the commonly found continuous IgM deposits in SLE, IgM deposits in the basal membrane zone of other forms of LE or other systemic connective tissue disease were mostly non-continuous (tables 1 and 3). Noncontinuous IgM deposits at the basal membrane zone, however, have also been found in 13-21\% of normal subjects, ${ }^{7-9}$ and possibly represent a physiological process.

Granular deposits of immunoreactants (IgA, IgG, IgM, C3) in blood vessel walls were shown to be significantly more common in patients with SLE than in other LE forms and systemic connective tissue disease (table 1 ). From this study it transpires that, especially in SLE, immunoreactants are found in superficial and deeper vessels (table 4). In normal subjects, IgA was seen in $0-1 \%$, IgG in $0-16 \%$, IgM in $1-65 \%$, and $\mathrm{C} 3$ in $1-35 \% .^{7-9}$ Previously there have been two studies in patients with SLE about this phenomenon with diverse results: IgA was shown in 5 and $6 \%, \operatorname{IgG}$ in 0 and $3 \%$, IgM in 15 and $47 \%$, and C3 in 9 and $34 \%$. ${ }^{15-21}$ The variation between these studies and between these and our present study may be due to the fact that smaller particles in vessel walls are easily overlooked. Deposits of IgA in the superficial vessels of clinically healthy skin have been shown to be a marker for IgA nephropathy, Henoch-Schönlein purpura, and alcoholic liver disease, but the fine granular particles seen in these disorders differ markedly from those in SLE. ${ }^{22}{ }^{23}$ In addition, these deposits were also found in $6 \%$ of a large group of patients with diseases not related to these disorders or to SLE. ${ }^{23}$

The significance of IgG deposits in the epidermal cell nuclei (in vivo antinuclear antibody staining phenomenon) has been reported. ${ }^{11}$ We have found that the in vivo antinuclear antibody phenomenon does not discriminate between SLE and other systemic connective tissue disease or LE forms, except for the homogeneous and thready patterns which are found exclusively in SLE. In this study it was found that in vivo antinuclear antibody staining without any immunoreactants at the basal membrane zone was present in $7 \%$ of other LE forms and $23 \%$ of the systemic connective tissue disease group, but entirely absent in SLE.

Combinations of immunofluorescence parameters give better results than individual parameters, judged by the statistical analysis (tables 5 and 6). Compared with the statistical values of the variables in the ARA criteria database, immunofluorescence microscopy, had it been included, would have been one of the best. $^{3}$

An important question is whether immunofluorescence microscopy of skin gives additional information compared with the ARA criteria. In the group of patients with SLE, seven statistically significant associations were found between five immunofluorescence variables and five ARA criteria (table 7). In three of these associations the occurrence of the immunofluorescence variables was significantly higher than the occurrence of the corresponding ARA criterion, indicating that these immunofluorescence variables may be more valuable diagnostic indicators. In one of the associations the ARA criterion was preferable; in three associations the two did equally well.

In this study no relationship was found between basal membrane zone deposits and nephropathy (based on blood tests and urine analysis, as defined in the 1982 ARA criteria ${ }^{3}$ ). Other investigations using laboratory parameters to analyse renal disease also showed ambiguous results. ${ }^{24}$ Several excellent studies comparing skin and kidney biopsy samples have, however, firmly established that basal membrane zone deposits show a positive correlation with more serious forms of lupus nephritis (class III and IV). ${ }^{24} 25$

The associations found between IgG at the basal membrane zone and serum antinuclear antibodies and antibodies to double stranded DNA, also found by others, ${ }^{24}$ support the theory that the deposits are complexes of DNA and antibodies to DNA. In this hypothesis DNA is not lost through the epidermis, ${ }^{26}$ but migrates from the decaying keratinocyte into the dermis, where it binds to collagen. ${ }^{27}$ Studies using acid elution and excess antigen to dissociate the immune complexes have shown the presence of antibodies to nuclear components in the basal membrane zone. ${ }^{28-30}$

The associations between IgG and IgA in the basal membrane zone and $\mathrm{C} 3$ in the blood vessels with malar rash, and between IgG at the basal membrane zone and light sensitivity, may point to a pathogenic relation. As these deposits were found in clinically normal skin, however, additional factors must play a part in the development of clinically manifest disease.

The immunofluorescence biopsy of clinically healthy forearm skin is a relatively simple method. When performed with the correct antiseptic measures, the wound heals without 
delay. In our hospital biopsy samples are taken satisfactorily by rheumatologists, internists, and dermatologists. From a technical point of view, the method is far less complicated than, for example, immunoblotting. We therefore see no reason why it should not be performed more regularly.

In the past, the diverse and complicated immunofluorescence patterns in SLE have been unduly reduced to the mere presence or absence of the lupus band. This study indicates that there is more than just the lupus band. Immunohistology of the skin, if performed as described here, can provide information not obtainable by other laboratory methods. Immunofluorescence microscopy of the skin therefore deserves to be considered seriously for inclusion as a diagnostic parameter for SLE, and should be reconsidered in an evaluation of the ARA criteria.

The authors gratefully acknowledge the skilful technical assistance of Miss J J Nefkens and Miss G C F de Bruin, and the critical comments of Dr C Nieboer and Dr P C M de Wilde.

I Dahl M V. Usefulness of direct immunofluorescence in patients with lupus erythematosus. Arch Dermatol 1983; 119: 1010-7.

2 Davis B D, Gilliam I N. Prognostic significance of sub epidermal immune deposits in uninvolved skin of patients
with systemic lupus erythematosus; a 10-year longitudinal with systemic lupus erythematosus; a 10-

3 Tan E M, Cohen A S, Fries J F, et al. The 1982 revised criteria for the classification of systemic lupus erythematosus. Arthritis Rheum 1982; 25: 1271-7.

4 Levetin P M, Weary P E, Giuliano V J. The immunofluorescent "band" test in mixed connective tissue disease. Ann Intern Med 1975; 83: 53-5.

5 Ma A S P, Soltani K, Bristol L A, Bernstein J E, Sorensen L B. Cutaneous immunofluorescence studies in adult rheumatoid arthritis in sun-exposed and non-sun-exposed areas. Int 7 Dermatol 1984; 23: 269-72.

6 Velthuis P J, Hene R J, Nieboer C, Kater L. A prospective immunofluorescence study of immune deposits in the skin of primary Siögren's syndrome. Acta Derm Venereol of primary Sjögren's syndr
(Stockh) 1989; 69: 487-91.

7 Baart de la Faille-Kuyper E H, van der Meer J B, Baart de la Faille H. An immunohistochemical study of the skin in healthy individuals. Acta Derm Venereol (Stockh) 1974; 54 $271-4$

8 Blenkinsopp W K, Claytin R J, Haffenden G P. Immunoglobulin and complement in normal skin. $\mathcal{F}$ Clin Patho 1978; 31: 1143-6.

9 Nieboer C. Immunofluorescence patterns in sun-exposed and not-sunexposed skin in healthy individuals. Acta Derm Venereol (Stockh) 1981; 61: 471-9.

10 Smith C D, Marino C, Rothfield N F. The clinical utility of the lupus band test. Arthritis Rheum 1984; 27: 382-7.

11 Velthuis $P$ J, Kater $L$, van der Tweel I, et al. In vivo ANA of the skin: its diagnostic signiticance and association with selective antinuclear antibodies. Ann Rheum Dis 1990; 49 163-9.

12 Ueki $\mathrm{H}$, Wolff $\mathrm{H} \mathrm{H}$, Braun-Falco O. Cutaneous localization of human gamma-globulins in lupus erythematosus. An electron-microscopical study using the peroxidase-labeled antibody technique. Arch Derm Forsch 1974; 248: 297-314.

13 Pehamberger H, Konrad K, Holubar K. Immunoelectron microscopy of skin in lupus erythematosus. $\mathcal{f}$ Cutan Pathol 1978; 5: 319-28.

14 Halevy S, Ben-Bassat M, Joshua H, Hazaz B, Feuerman E J. Immunofluorescent and electron-microscope findings in Immunofluorescent and electron-microscope findings in the uninvolved skin of patients with lupus eryth
Acta Dermat Venereol (Stockh) 1979; 59: 427-33.

15 Morris R J, Guggenheim S J, McIntosh R M, Rubin R L Kohler P'F. Simultaneous immunologic studies of skin and kidney in systemic lupus erythematosus. Arthritis Rheum 1979; 22: 864-70.

16 Sontheimer R D, Thomas J R, Gilliam J N. Subacute cutaneous lupus erythematosus. Arch Dermatol 1979; 115 $1409-15$

17 Bangert J L, Freeman R G, Sontheimer R D, Gilliam J N Subacute cutaneous lupus erythematosus and discoid lupus erythematosus. Comparative histopathologic findings. Arch Dermatol 1984; 120: 332-7.

18 McCarty D J, ed. Arthritis and allied conditions, a textbook of rheumatology. Philadelphia: Lea \& Febinger, 1989.

19 Zubler R H, Lange G, Lambert P H, Miescher P A Detection of immune complexes in unheated sera by Detection of immune complexes in unheated sera by modified

20 Cats A, Lafeber G J M, Klein F. Immunoglobulin phagocytosis by granulocytes from sera and synovial fluids in various rheumatoid and nonrheumatoid diseases. Ann Rheum Dis 1975; 34: 146-55.

21 O'Loughlin S, Schroeter A L, Jordon R E. A study of lupus erythematosus with particular reference to generalised discoid lupus. $B r \mathcal{F}$ Dermatol 1978; 99: 1-11.

22 Baart de la Faille-Kuyper E H, Kater L, Kuyten R H, Kooiker C J, Wagenaar SiS, van der Zouwen P, Dorhou Mees E J. Occurrence of vascular IgA deposits in clinically normal skin of patients with renal diseases. Kidney Int normal skin of

23 Hené R J, Velthuis P J, van de Wiel A, Klepper D, Dorhou Mees E J, Kater $L$. The relevance of IgA deposits in vesse walls of clinically healthy skin. A prospective study. Arch Intern Med 1986; 146: 745-9.

24 Provost T T, Andres G, Maddisson P J, Reichlin M. Lupus band test in untreated SLE patients: correlation of immunoglobulin deposits in the skin of the extenso forearm with clinical renal disease and serological abnormalities. $\mathcal{F}$ Invest Dermatol 1980; 74: 407-12.

25 Halberg $P$, Ullman $S$, Jorgensen $F$. The lupus band test as a measure of disease activity in systemic lupus erythematosus. measure of disease activity in system

26 Fukuyama K, Bernstein I A. Autoradiographic studies of the incorporation of thymidine-H3 into deoxyribonucleic acid incorporation of thymidine-H3 into deoxyribonu

27 Izui S, Lambert P-H, Miescher P A. In vitro demonstration of a particular affinity of glomerular basement membran and collagen for DNA. $\mathcal{F}$ Exp Med 1976; 144: 428-43.

28 Landry M, Sams W M. Systemic lupus erythematosus. Studies of the antibodies bound to skin. $\mathcal{F}$ Clin Invest 1973 52: $1871-80$.

29 Thivolet J, Beyvin A J, Le Mot J. Elution des anticorps fixés in vivo au niveau de la peau au cours du pemphigus de la pemphigoide bulleuse et du lupus érythémateux. Lyon Med 1972; 227: 241-5.

30 Feltkamp $T$ E W, Boode $J \mathbf{H}$. Elution of antibodies from biopsy tissue. $\mathcal{F}$ Clin Pathol 1970; 23: 629-31. 